\title{
Students' Perception on the Affecting Factors in Writing Descriptive Essays
}

\author{
Netty Kumala Dewi ${ }^{1 *}$, Jumariati ${ }^{2}$, Yusuf Al-Arief ${ }^{3}$ \\ ${ }^{1,2,3}$ Lambung Mangkurat University \\ "Corresponding author. Email: $1710117320033 @ m h s . u l m . a c . i d$
}

\begin{abstract}
Writing essays for EFL students is uneasy since they should have extensive knowledge on the topic, a good language use in vocabulary, grammar, and punctuation, and good motivation in writing. There are some factors that underlie these problems. This study aimed to find out students' perceptions on the affecting factors in writing descriptive essay. This research used a qualitative approach involving 41 students of Advanced Writing class. It utilized questionnaire and interview guideline. The findings showed that every student had distinctive factors that affected them in writing. Internal factors were those that come from inner student such as low motivation, limited vocabulary, lack of knowledge on organizing ideas, and low interest on the topics. Meanwhile, external factors were those that came from outside the individual such as learning atmosphere, learning facilities including dictionaries, hand phones, and laptops, and the role of their classmates and lecturers in writing descriptive essays. Based on the findings, it is suggested to the students to overcome the problems by brainstorming or outlining to help them organize idea. It is also suggested to them to maintain good motivation and interest in writing. Finally, it is recommended to conduct further study to solve EFL students' problems in writing and reduce the factors that hinder them in developing their writing skills.
\end{abstract}

Keywords: Writing essays, Affecting factors, Perception.

\section{INTRODUCTION}

One of the English skills that enable students to express their ideas is writing. Writing encourages students to focus on appropriate language use, they can go through what they know in their mind, and even see dictionaries, grammar books, or other references [1]. There are several kinds of writing starting from writing a sentence, writing a paragraph, writing an essay, to writing a paper. In fact, writing is the hardest skill for second language learners [2]. Furthermore, writing is considered as a difficult skill, as the problems include linguistic proficiency below the standard (such as grammar, syntax, and vocabulary), writing anxiety, lack of ideas, reliance on L1 and weak structure organization [16]. The difficulty lies not only in generating and organizing ideas but also in translating ideas into readable text.

Writing is challenging for EFL learners because they have problems in the content, vocabulary, grammar, organization, and mechanics [3]. Other factors such as the students' dislike towards this skill also becomes problem for them in writing [17]. Moreover, students have difficulty when they are asked to write about topics they are not interested in doing. This implies that writing is not merely about expressing idea in sentences but internalizing one's ability in using proper word, grammar, and organization in a piece of acceptable and readable writing. It is how the writer presents and expresses these ideas effectively. Particularly in writing essays, students should have the ability to develop the main idea into a cohesive and coherent piece of writing. Hence, it is important for teachers to know how their students develop their skills in writing, particularly in writing essays.

Students need to feel competent as writers and motivated to write in order to improve their writing skills. They also need to acknowledge the benefits of having writing skills and maintain their interest in writing. This is because students' motivation to write is influenced by their perceptions on writing competence [4]. Perception is the way someone acts according to a thing that they learn towards using something, whether they approve or not of the method or about the thing they learn [5]. In this case, the learning activities which motivate students in writing a descriptive essay are 
essential to creating various perspectives from each student, since every perception will emerge from every student's experience. Hence, it is important to create a learning environment that is efficient and effective to encourage students in doing writing activities.

There are various factors which affect students in learning language skills both derived from internal and external factors. The internal factors include physical health, leisure time availability, hobby or passion, selfmaturity, and intelligence Meanwhile, external factors include family and friends' support, faculty facilities, problems encountered, peer relationships, and the influence of parents and friends [6]. Not only students, but also teachers experience problems in teaching writing including students' language ability, students' motivation, classroom situation, and lack of lesson hours [18]. However, since there are different kinds of affecting factors in every student which relates to individuals' perception that cannot be equal from each others, it is essential to investigate students' perception on the factors that affect them in writing.

Studies have been conducted to reveal EFL students' problems in writing. From the perspective of students, a study which inquired students' perception in writing procedure text confirmed that most students were aware of their own skill in writing procedure text, although more practice is needed for the students to improve this skill [13]. Meanwhile, good method might have been applied by the teacher in teaching procedure text writing. In another study involving 38 undergraduate EFL students discovered that students had high level of anxiety in English writing, with cognitive anxiety being the most suffered by the students [15]. Neither gender nor the perception of writing difficulties gave any impact to the level of anxiety. Interestingly, however, grammar was the most feared by the students.

Another investigation revealed that the students experienced primary obstacles in grammar, cohesion, and coherence, and expected more guidance from the lecturer to improve their essays [19]. It is also admitted by the lecturer that the lack of time and the large quantity of the students in a class at a time are his most obstacles in this regard. The perspective of teachers is also considered in some research. As discovered in a study by Hang [17], that despite their comprehension of the necessity of teaching writing, their confidence, and appropriate pedagogical usage and content knowledge in teaching it, the teachers in Vietnamese mentioned that they are hindered by the limited time, the difficult contents in textbooks, multiple-choice test formats, large classes, students' lack of interest toward this skill, and their lack of grammar knowledge and vocabulary to teach writing skill.
However, only few research had been conducted in regards of EFL students' perception, especially towards writing descriptive essay. Given that descriptive essay is important to learn as it belongs to the type of essay and can train students' ability in describing things, there is a need to conduct a research that investigates the students' perception on descriptive essay. It is necessary since the students' perception can affect the result of their writing [12]. Moreover, this study may reveal the thoughts of the students of themselves and their view on descriptive essay. Hence, the research question is formulated into "How are the students of English Language Education Program Batch 2019 perceive the affecting factors in writing a descriptive essay?"

\section{LITERATURE REVIEW}

Writing involves both content and a variety of linguistic approaches [7]. Moreover, writing evokes thinking and learning, because it involves communication and thought in a reflection. Ideas can be studied, reviewed, attached to, corrected, and modified once written down. The point is that writing is often a continuing process of discovery; when writing, it is possible to suddenly switch directions or come double back; for instance, when the writer writes the body paragraphs, he may return to the introductory paragraph to make some adjustments or changes. Writing is both physical and a mental act [8]. At the most basic level, writing is a physical action that carries words or ideas into a medium, whether inked hieroglyphics or typed email messages. However, writing is also a mental work to create ideas, think of ways to express them, and organize them into clear statements and paragraphs for the reader.

To make a good writing, the writer needs to go through certain process of writing. There are four main elements such as planning, drafting, editing, and writing the final version [1]. It means, the writing process starts with good planning. The writer plans what ideas or topics that will be discussed. Then, the ideas that have been made are arranged into sentences. After the writing is complete, the writer checks the organization, cohesiveness, grammar, and spelling. If something is not right, the writer should revise it until he produces a piece of writing that can be read by the readers.

However, writing in a foreign language is challenging [3]. There are various factors that affect EFL students in developing their writing skills. Factors that affect student learning outcomes can be classified into two, namely external factors and internal factors [12]. 


\subsection{External Factors}

External factors are those that come from outside the individual, namely the conditions in the environment around students and supporting facilities such as smartphones, laptops, books and others. There are external factors that can influence student writing:

\subsubsection{Family}

Family conditions greatly affect the success of children. The way parents teach their kids, the economic status of the family, and parental guidance can affect a child in learning.

\subsubsection{Environment}

If a child lives in a community which consists of well-educated and well-behaved people and the conditions around the house are comfortable, it can affect students' learning and facilitate better achievement.

\subsubsection{School}

The school's social environments such as teachers, administrative staff, and classmates can affect a student's enthusiasm for learning. The role of the teacher is very important in the student learning process which helps them to be skilled in writing. In learning writing, the teacher's ability to deliver material and explain it to students is very important. A teacher should apply a suitable method or technique in teaching to create the desired learning atmosphere.

\subsection{Internal Factors}

Internal factors are those that come from the individual student which include psychology, interests, talent, and motivation.

\subsubsection{Psychology}

Psychological factors are those factors of habits or experiences that students have. The more accustomed to writing, the better the students' writing skills and quality will be.

\subsubsection{Interests}

Interest has a great influence on students' writing skills, because if the subject matter and material being studied are not in accordance with the student's interest, the student cannot develop his writing skills properly. One way to increase students' interest in writing is to provide them with themes related to their lives and needs.

\subsubsection{Talent}

Talent is a person's ability to learn. Talent can affect students' writing skills, because if students have talent in writing, they will be more active in developing their writing skills and be able to do various writing tasks well.

\subsubsection{Motivation}

Motivation is a condition contained in a person that encourages him to carry out certain activities in order to achieve a goal. In the learning process, it is necessary to pay attention to what can encourage students to be motivated in developing their various skills, for example providing motivation to students in the form of prizes when they have finished writing.

Every student has their own perception of how the teacher or lecturer explains lessons in the classroom. Even though students receive the same instructions at the same time from the same teacher in the classroom, they will interpret the experience differently and take different things from the lesson. As the result, they will have different perceptions of something from each other [20]. Each student has their own needs and goals in writing. Therefore, it is necessary to investigate what factors that affect students in writing so that teachers or lecturers can understand what the students need. It is also fruitful since understanding the students' needs can make the teachers evaluate whether their way of teaching is appropriate or not.

\section{METHOD}

This research applied a descriptive design with qualitative approach. A questionnaire and interview guidelines were utilized to collect the data. The subjects of the research were the students of English Language Education Study Program who were enrolled in Advanced Writing course and selected by using purposive sampling. Furthermore, some subjects were selected to be interviewed to explore much information about their perceptions on the affecting factors in writing descriptive essay. The data from the questionnaire was analyzed and used as the basis to select the subjects to be interviewed. Finally, the data from the interview was transcribed and classified into sub themes regarding the internal factors and external which affect students in writing descriptive essays.

\section{RESULT AND DISCUSSION}

\subsection{Students' Interest}

The first indicator is student's interest. The results of the interview regarding student interest showed that they had a strong interest in writing and enjoyed the process of learning to write. Students 2 said "I have always enjoyed learning English, I like watching people speak English. It makes me to want to be like them. Since the beginning, I was interested in learning English. It came from inside which motivates me to improve myself. It is also because the lecturers encourage me and guide me". 
The second interviewee also told his experience in learning writing, "The reason I like writing because in writing we can give our ideas, with our style and what we write can be conveyed and well structured, we can revise the parts that we feel are not correct in writing and in learning writing we can assess how well we can explore our ideas and use of words in written form. Of course, it's different from learning to speak, where sometimes we forget what we want to convey".

From the interview, some of the subjects gave neutral responses and even expressed disinterest in writing. Student 3 said, "For me, it depends on the topic. If it is a hard topic like politics or something related to that, I would not like it because it is too hard for me. But if it is like a cartoon or something like funny topics I would certainly like it and interested on it".

Another student also gave a negative statement by stating “Actually, I don't really like writing because when we write something and we want to make it good writing we have to be a critical person and I am not that critical person. So I don't really like to write because I don't have skill in it. Then, when we write we take a long time to make a good writing. So that's why I don't really like writing".

\subsection{Students' Knowledge}

The second indicator is students' knowledge. From the results of the interview, students already understood the purpose of writing descriptive essays because they had studied and written essays in writing courses. In addition, students also know the structure of descriptive essays. The following is the results of the interview:

Student 1 stated "I know descriptive essays; I studied about them when I was in high school. The description essay is describing something from general, then we will narrow it down again. A descriptive essay uses the simple present tense. Thus, we describe something into an essay." After that, the interviewee also explained what she/he got from writing descriptive essays, "I think I can describe something and convey my idea. I learn the rules of descriptive essays like what grammar and tenses we use and what the patterns are and I can learn how to describe things in a good way like from the general first to the deeper ones".

The second interviewee is the one who represents a neutral statement about they know what a descriptive essay is but do not know much about its structure. The student said "I think it describes objects, animals, and others as far as I know in general".

The third interviewee stated, "I know. But I have never written a descriptive essay before".

\subsection{Students' Difficulty}

The third indicator is students' difficulty. The results of the interview show that most of the students still had difficulties in writing descriptive essays. These difficulties are what hinder them in writing. Student 1 stated "My biggest weakness in writing is how to start even though I already had brainstorming or made an outline, sometimes when I want to start writing suddenly, I get blank. That's why I consider it as my difficulties in writing".

Another student stated, "The difficulty is the limited vocabulary. Because of the limited vocabulary that I know, sometimes I cannot write. I also feel difficult to write essays like descriptive and argumentative because they have rules. I have difficulty in understanding it, such as how to write the background, the body paragraph, and the conclusion".

Besides, another student also had the same problem by stating "Personally, it is difficult to write in academics setting like writing essays. My difficulty was in writing the introduction and body of the essay because I usually write too many things so that the main idea was lost. So, my weakness is there. I can write a good topic sentence but when I write the body, the sentences are out of context. In addition, I feel difficult to use formal style in writing so I often use informal words. Sometimes I also have problem with the time allocation for writing an essay."

Another interviewee also gave his/her answer, "My difficulty is in the context. Unlike formal writing which has the context that really supports the statement. However, descriptive essay has the context, but we have to be able to adjust the context according to the descriptive essay."

\subsection{Students' Need}

The results of the interview on the fourth indicator showed that most of the students had certain factors that help them in writing descriptive essays namely topics familiarity, a quiet and tidy place, brainstorming, and the permission of using smartphones or laptops that enable them to check grammar, spelling, and use a translation machine. The following is the results of the interview.

Student 1 stated "Usually my preparation for writing a descriptive essay is imagining first like writing the draft first, so that later when I write it, the sentences can be more organized. Another factor that helps me when writing is writing while listening to music.Then, the temperature of the room is cold and it should not be dark. I also like drinking coffee while writing. But in the classroom, when it is allowed, I listen to music through my earphones to focus on myself and not be distracted by others".

Student 2 gave another response, "The preparation I need when writing a descriptive essay, first I find information about the topic if the topic is unfamiliar for me because it will be difficult to write things that I do not know much. Because when we describe something, we automatically have to know the thing from the inside 
and outside and know the strengths and weaknesses. So automatically knowledge is the most important thing. And then, the surrounding situation that provides me peace for framing the things we describe. In addition, the factors that help when writing descriptive essays are listening to music and the quiet atmosphere."

The next interviewee stated, "Like brainstorming and outlining because it really helps me who have a hard time writing essays. In addition, enjoyable atmosphere, relaxed without pressure, and motivation from classmates make me enjoy writing even more enthusiastic."

The last interviewee responded, "I usually prepare dictionary to help me with vocabulary. And I also prepare my hand phone and laptop with the internet connection so I can browse sources and references related to the topics assigned."

Based on the findings, it can be concluded that the student' interest was influenced by external and internal factors for instance their own experiences since childhood wherein they liked to write and read books. Besides, support from classmates and lecturers also help them in writing better essays. This result was compatible with the theory by Dalyono [12] that stated "factors that affect student learning outcomes can be classified into two, namely external factors and internal factors." Moreover, other factors such as the students' dislike towards this skill can also become problem for them in writing [17], as it is proven by some students with low interest towards writing descriptive essay that admitted that it is because it took a long time for them to produce a good writing.

Most students knew about essay descriptions. However, apart from these students who knew more about essay descriptions, there were also some students who did not know what a descriptive essay was specifically such as the writing and the steps needed when writing an essay. This finding was consistent with the statement by Karlsen and Gottschalk [14] that define knowledge as information associated with experience, context, interpretation, thinking, intuition and creativity. It can be said that in writing descriptive essays, the students' knowledge is information, associated with experience, context, interpretation, thinking, intuition and creativity. Therefore, students' understanding related to structure, language features of descriptive essays, and their knowledge of the purpose of descriptive essays as well as their experiences with writing descriptive essays could affect them in writing.

Meanwhile, the majority of students had difficulties when writing a descriptive essay such as their illiteracy of the tense used, limited vocabulary, lack of knowledge and interest about the topic, students' difficulties in organizing ideas, and students' difficulty to write within the time allocated. As previous research reveal, for EFL learners, writing is challenging because they have problems in the content, vocabulary, grammar, organization, and mechanics [3] [15]. Moreover, it is proven that writing involves both content and a variety of linguistic approaches [7]. All of these become the struggles for the students to compose a descriptive essay since they need both in-context content and appropriate linguistic approaches for an essay.

Moreover, the majority of the students stated that certain factors help them in writing descriptive essays namely topics familiarity, a relaxed atmosphere, a quiet and tidy room, motivation from classmates and lecturers, and learning facilities like dictionaries, hand phones, and laptops. However, in these kinds of situations, writing encourages them to focus on appropriate language use; they can go through what they know in their mind, and even see dictionaries, grammar books, or other references [1]. Furthermore, students' motivation to write is influenced by their perceptions on writing competence [4], thus decides their act regarding to writing descriptive essay.

The finding is similar to that of a study by Widayanti, Rustyana, and Handayani [13] that most students were aware of their own skill in writing, although more practice are needed. The findings elaborated above are also consistent with the theory that "factors that affect student learning outcomes can be categorized into two: external factors and internal factors" [12]. It can be concluded that every student has certain factors that affect them in writing a descriptive essay namely internal factors and external factors.

\section{CONCLUSION}

The data analysis of students' perception on the affecting factors in writing descriptive essay confirmed that the students have problems in writing descriptive essays pertaining to limited vocabulary, lack of knowledge on organizing ideas, lack of knowledge on formal writings, lack of motivation, and limited time for accomplishing a piece of writing. Moreover, there are certain factors that affect students in writing namely students' interest, students' motivation, topics familiarity, the need of relaxed atmosphere while writing, the need of a quiet and tidy room, motivation from classmates and lecturers, and the facilities for learning which include dictionary, hand phone, and laptops. These findings imply that there are internal factors and external factors that affect students in writing. Hence, it is suggested to the students to do brainstorming or outlining to organize their idea and maintain good motivation and interest in essays writing. Finally, it is recommended to conduct further study to solve the students' problems in writing and reduce the factors that hinder them in developing writing skills. 


\section{AUTHORS' CONTRIBUTIONS}

Author 1 contributed to the reviewing of literature, designing research instruments, collecting the data, and analyzing the data. Author 2 contributed to the data analysis and writing the report. Author 3 contributed to literature review and writing format.

\section{ACKNOWLEDGMENTS}

The authors are very thankful to all the subjects of the research who were willing to participate in the survey and interviews which make this study possible.

\section{REFERENCES}

[1] J. Harmer, The practice of English language teaching, Pearson Education Limited, England, 2004.

[2] J. C. Richards, W. A. Renandya, Methodology in Language. Teaching: An Anthology of Current Practice, Cambridge University, 2002.

[3] J. Jumariati, G. H. Sulistyo, Problem-Based Writing Instruction: Its Effect on Students' Skills in Argumentative Writing, in: Proceedins of Arab World English Journal, vol. 8, 2017, pp. 87-100, DOI: 10.24093/awej/vol8no2.6.

[4] P. Boscolo, C. Gelati, Best Practices in Promoting Motivation for writing, in: S. Graham, C.A. MacArthur, \& J. Fitzgerald. Best practices in writing instruction, Guilford, New York, 2007.

[5] K. S. Hong, A. A. Ridzuan, M. K. Kuek, Students' Attitudes Toward the Use of the Internet for Learning: A study at University in Malaysia, in: Proceedings of Educational Technology \& Society, vol. 6, 2003, pp. 45-49.

[6] H. Nyambe, H. Harsono, G.R. Rahayu, Factors influence self-directed learning readiness of first, second and third years students at medical faculty of Hasanuddin University in PBL, in:Proceedings of Indonesian Journal of Medical Education, vol 5 2016, pp. 67-77.

[7] A. Musa, S. Hussin, I. A. Ho, Interaction in Academic L2 writing: An analysis of Interactional Metadiscourse Strategies in Applied Linguistics Research Articles, in: Proceedings of 3L: The Southeast Asian Journal of English Language Studies, vol. 25, 2019, pp. 16-32.

[8] D. Nunan, Practical English Language Teaching (Eds.), McGraw-Hill Companies, Inc, United States, 2003.

[9] Eripuddin, An Analysis of Students' Essay at English Department of University Pasir
Pengaraian, in: Proceedings of Educational Research, vol. 5, 2016, pp. 1-4.

[10] A. Oshima, A. Hogue, Writing Academic English, Longman, United States, 2006.

[11] A.W. Pratama, The Influence of Students' Mastery of Idiom on Their Writing Skill of Descriptive Essay, Walisongo State Islamic University, 2019.

[12] D. Dalyono, Psikologi Pendidikan, PT. Rineka Cipta, Jakarta, 2005.

[13] T. Widayanti, N. Rustyana, A. Haryudin, Students' Perception in Writing Procedure Text, in: Proceedings of PROJECT: Professional Journal of English Education, vol. 2, 2019, pp. 687-691.

[14] J. T. Karlsen, P. Gottschalk, Factors affecting knowledge transfer in IT projects, in: Proceedings of Engineering Management Journal, vol. 16, 2004, pp. 3-10.

[15] H. Hartono, M. M. Maharani, English Writing Anxiety and the Writing Problems of Indonesia EFL Learners, in: Proceedings of Advances in Social Science, Education and Humanities Research, vol. 409, 2020, pp. 513-517.

[16] M. Fareed, A. Ashraf, M. Bilal, ESL Learners' Writing Skills: Problems, Factors and Suggestions, in: Proceedings of Journal of Education and Social Sciences, vol. 4, 2016, pp. 81-92.

[17] N. T. T. Hang, Vietnamese upper-high school teachers' views, practices, difficulties, and expectations on teaching EFL writing, in: Proceedings of Journal on English as a Foreign Language, vol. 11, no. 1, 2021, pp. 1-20.

[18] K. H. Hidayati, Teaching Writing to EFL Learners: An Investigation of Challenges Confronted by Indonesian Teachers, in: Proceedings of LANGKAWI: Journal of The Association for Arabic and English, vol. 4, no. 1, 2018, pp. 21-31.

[19] A. Ariyanti, R. Fitriana, EFL Students' Difficulties and Needs in Essay Writing, in: Proceedings of Advances in Social Science, Education and Humanities Research, vol. 158, 2017, pp. 111-121.

[20] Z. Zulfikar, C. T. Aulia, Exploring Acehnese EFL College Students' Perceptions on Collaborative Writing, in: Proceedings of Wanastra: Jurnal Bahasa dan Sastra, vol. 12, 2020, pp. 171-180. 